\title{
ERRATUM
}

\author{
S. R. Roux $\cdot$ B. Hackauf $\cdot$ A. Linz $\cdot$ B. Ruge
}

B. Klocke $\cdot$ P. Wehling

\section{Leaf-rust resistance in rye (Secale cereale L.). 2. Genetic analysis and mapping of resistance genes Pr3, Pr4, and Pr5}

Published online: 6 October 2004

(C) Springer-Verlag 2004

\section{Theor Appl Genet (2004)}

DOI 10.1007/s00122-004-1807-5

In Table 3, the number of resistant plants in families BAZ-60003 and BAZ-1086 comprises both homozygous resistant and heterozygous resistant individuals.

The online version of the original article can be found at http:// dx.doi.org/10.1007/s00122-004-1807-5

S. R. Roux $(\bowtie) \cdot$ B. Hackauf $\cdot$ A. Linz $\cdot$ B. Ruge $\cdot$ P. Wehling Institute of Agricultural Crops,

Federal Centre for Breeding Research on Cultivated Plants (BAZ), Rudolf-Schick-Platz 3a,

18190 Gross Lüsewitz, Germany

E-mail: bafz-lk@bafz.de

Fax: + 49-38209-45222

B. Klocke

Institute of Plant Breeding and Plant Protection,

Martin-Luther-Universität Halle-Wittenberg,

Ludwig-Wucherer-Str. 2, 06108 Halle, Germany 